\title{
Pengaruh Pemotongan Daun dan Pemberian Konsentrasi Ekstrak Bawang Merah terhadap Pertumbuhan Setek Kopi Robusta (Coffea canephora $\mathbf{P}$.)
}

\author{
I GEDE BUDI YUDA KUMARA, I WAYAN PASEK ARIMBAWA*), DAN \\ I NYOMAN SUTEDJA
}

\author{
Program Studi Agroekoteknologi Fakultas Pertanian Universitas Udayana \\ Jl. PB. Sudirman Denpasar 80232 Bali \\ ${ }^{*}$ E-mail: iwayanpasekarimbawa@gmail.com
}

\begin{abstract}
Effect of Leaf Cutting and Concentration of Shallot Extract on the Growth of Cuttings Robusta Coffee (Coffea canephora P.). Robusta coffee plants (Coffea canephora P.) in general can be reproduced generatively by seeds, while the vegetative method can be done by grafting, cuttings, and tissue culture. Breeding of robusta coffee by generative method was often unsatisfactory, therefore the propagation of Robusta coffee is recommended using vegetative methods, namely cuttings. This study aims to determine the effect of leaf area cutting and the concentration of shallot extract and its interaction on the growth of Robusta coffee cuttings. This study used 2 factors in factorial design, namely: percentage of leaf cutting and the concentration of shallot extract. Variables observed were shoots growth time, shoots length, shoots diameter, number of leaves of seedling, leaf area of seedling, number of primary roots, length of primary root, oven dry weight of the root, oven dry weight of shoots, leaf oven weight, photosynthetic partition coefficient and total dry weight of plants.The results of this study showed that the best growth of Robusta coffee cuttings was shown in the $0 \%$ leaf cutting treatment with the heaviest total dry weight of the seedlings, which was $4.35 \mathrm{~g}$ and experienced an increase of $131.38 \%$ compared with $75 \%$ leaf cutting. Interaction of $0 \%$ leaf cutting by giving the concentration of onion extract $25 \%$ is the best treatment, this can be seen from the observation of the primary root length, but the total oven dry weight showed no significant difference.
\end{abstract}

Keywords: Concentration of shallot extract, leaf cutting, nurseries, robusta coffee

\section{PENDAHULUAN$$
\text { PENDAHULUAN }
$$

memiliki 3 jenis kopi yaitu arabica, robusta

$$
\begin{aligned}
& \text { Kopi merupakan salah satu jenis dan liberika.Produksi kopi yang dihasilkan di } \\
& \text { tanaman perkebunan yang sudah lama Indonesia tahun } 2017 \text { yaitu } 463.775 \text { ton per } \\
& \text { dibudidayakan dan memiliki nilai ekonomis tahun dari luas areal } 887.288 \text { hektar } \\
& \text { yang cukup tinggi. Secara umum Indonesia (Direktorat Jenderal Perkebunan 2017). }
\end{aligned}
$$


I GEDE BUDI YUDA KUMARA. et al. Pengaruh Pemotongan Daun dan Pemberian Konsentrasi...

Produktivitas masih tergolong rendah, yaitu yang banyak, dapat ditanam dilahan marginal kurang lebih $500 \mathrm{~kg}$ biji kering per hektar per dan tahan nematode, Sifat-sifat tersebut tahun. Salah satu faktor yang diduga menjadi dimiliki oleh kopi robusta klon BP308.

penyebab rendahnya produktivitas kopi di Perbanyakan dengan setek adalah cara Indonesia khususnya kopi robusta adalah pembiakan tanaman dengan menggunakan sebagian besar tanaman kopi robusta sudah bagian vegetatif yang dipisahkan dari berumur tua. Usia ideal untuk tanaman kopi induknya sehingga mengasilkan tanaman baru yang produktif yakni 5 sampai dengan 20 yang memiliki sifat sama dengan induknya. tahun. Tanaman kopi dapat disebut tua jika Selain itu, perbanyakan dengan setek dapat telah melewati usia 20 tahun. Kenyataannya, mempertahankan kemurnian klon yang pada perkebunan-perkebunan kopi rakyat di dikehendaki, menghemat biji-biji kopi pada Indonesia masih ditemukan berumur hingga tempat-tempat yang sukar mendapatkan benih lebih dari 30 tahun. unggul atau pada suatu tahun dengan

Luas areal perkebunan kerja rakyat di produksi yang rendah, pertumbuhan dan Bali tahun 2015 yaitu 35,755 hektar, tanaman produksinya lebih seragam, akar serabut lebih tua atau tanaman rusak 2,463 hektar. Rata- banyak dan klon unggul dapat diperbanyak rata produktivitasnya $632 \mathrm{~kg} / \mathrm{ha}$ (Direktorat langsung dari pohon induknya. Pertumbuhan Jenderal Perkebunan 2016).

akar yang cepat akan memungkinkan sumber

Tantangan kedepan untuk perkebunan setek memperoleh nutrisi untuk menunjang kerja rakyat kopi robusta di Bali ialah untuk pertumbuhannya. Supaya mempercepat meningkatkan daya saing dalam hal pertumbuhan per-akaran setek, maka perlu produktivitas dengan cara meningkatkan dipacu dengan pemberian zat pengatur produksi dengan melakukan peremajaan tumbuhan.

menggunakan bibit klon unggul.

Bawang merah mengandung hormon

Tanaman kopi robusta di Bali, untuk auksin yang dapat memacu partumbuhan akar peremajaannya lebih banyak dilakukan setek tanaman. Menurut Marfirani et al. dengan cara pembiakan vegetatif yaitu (2014), pada bawang merah terdapat senyawa dengan cara setek dan sambung. Tanaman yang disebut allin yang kemudian akan sebagai batang bawah diupayakan yang berubah menjadi senyawa thiosulfinat seperti mempunyai sistem perakaran yang baik allicin. Allicin dengan thiamin (vitamin B) terutama perakaran yang melebar, akar lateral membentuk allithiaminyang memperlancar 
meta-bolisme padajaringan tumbuhan. Oleh luar sel. Difusi air akan meningkatkan karena itu, pemberian ekstrak bawang merah tekanan turgor di dalam sel, sehingga air akan pada awal penanaman setek batang tanaman masuk ke vakuola yang selanjutnya akan kopi robusta diharapkan dapat memacu mengatur pertumbuhan sel dan primordia pertumbuhan akar pada setek batang menjadi daun.

lebih cepat.

Daun merupakan tempat menghasilkan

Hormon tumbuh selain berfungsi karbohidrat yang dihasilkan dari proses sebagai perangsang keluarnya akar dan tunas, fotosintesis, oleh karena itu penyisaan daun juga dapat berfungsi sebagai penghambat pada bahan setek bertujuan agar fotosintesis pertumbuhan. Pada konsentrasi rendah tetap dapat berlangsung sehingga bahan setek hormon akan menggiatkan pertumbuhan akar, tetap dapat memperoleh energi(karbohidrat) sebaliknya semakin tinggi konsentrasinya untuk membantu dalam pembentukan tunas akan menghambat pertumbuhan akar. dan akar. Rochiman dan Harjadi (2003 dalam Berdasarkan hasil penelitian Siregar et al. Wulandari et al., 2017), menyatakan selain (2015) pemberian ekstrak bawang merah de- menghasilkan karbohidrat, daun juga ngan konsentrasi $75 \%$ memberikan hasil merupakan sumber auksin yang akan terbaik untuk pertumbuhan panjang akar, bergerak ke bawah dan akan menumpuk di panjang tunas dan jumlah tunas pada setek bagian dasar setek yang selanjutnya mawar. Utami et al. (2015) juga mendapatkan menstimulir pembentukan akar. Menurut bahwa pemberian konsentrasi ekstrak bawang Harjadi (1991 dalam Wulandari et al., 2017), merah memberikan pengaruh nyata pada laju respirasi dipengaruhi oleh banyak faktor variabel saat tumbuh tunas, tinggi tunas dan salah satunya adalah indeks luas daun jumlah daun. Konsentrasi ekstrak bawang tanaman.Maka dari itu luas daun pada setek merah 50\% adalah konsentrasi paling harus dipotong untuk mengurangi optimum untuk pertumbuhan setek anggur. kemungkinan terjadinya transpirasi yang Menurut Lakitan (2006 dalamHafizah, 2014) berlebihan.

mekanisme masuknya unsur hara dan zat Tujuan penelitian adalah untuk pengatur tumbuh dalam sel tanaman melalui mempelajari pengaruh pemberian konsentrasi proses difusi pada sel tanaman yang ekstrak bawang merah dan pemotongan daun, dipengaruhi oleh permeabilitas membran sel serta interaksinya terhadap pertumbuhan dan perbedaan potensial air di dalam dan di setek kopi robusta. 
I GEDE BUDI YUDA KUMARA. et al. Pengaruh Pemotongan Daun dan Pemberian Konsentrasi...

\section{BAHAN DAN METODE}

\section{Tempat dan Waktu Penelitian}

Percobaan ini dilakukan di kebun milik salah satu petani di Desa Belantih, Kecamatan Kintamani, Kabupaten Bangli dari Februari - Mei 2019.Analisis pengamatan dilakukan di Laboraturium Ekofisiologi Fakultas Pertanian Universitas Udayana.

\section{Alat dan Bahan}

Bahan yang digunakan yaitu tunas kopi robusta klon BP308, tanah, pasir, sekam padi, bawang merah, air dan kompos. Alat yang digunakan yaitu sungkup plastik transparan, dengan membentuk setengah lingkaran paranet, polybag, pisau, blender, kain kasa, seperti atap dengan mengunakan plastik ember, cangkul, gunting, gelas ukur, bening di sekelilingnya. Plastik bening yang timbangan analitik, pengaris, jangka sorong, mengelilingi tempat penanaman bertujuan alat tulis dan kamera.

\section{Rancangan Percobaan}

Penelitian mengunakan rancangan acak kelompok (RAK) faktorial dengan 2 faktor perlakuan. Faktor yang pertama, pemotongan luas daun yang terdiri atas 4 taraf yaitu $\mathrm{P}_{0}=$ Pemotongan luas daun 0\% (tanpa pemotongan), $\mathrm{P}_{1}=$ Pemotongan luas daun $25 \%, \mathrm{P}_{2}=$ Pemotongan luas daun 50\%, dan $\mathrm{P}_{3}=$ Pemotongan luas daun 75\%. Faktor kedua, pemberian konsentrasi ekstrak bawang merah yang terdiri dari 4 taraf yaitu $\mathrm{K}_{0}=$ 80
Konsentrasi 0\% (0 ml ekstrak bawang merah $+100 \mathrm{ml}$ air), $\mathrm{K}_{1}=$ Konsentrasi 25\% (25 ml ekstrak bawang merah $+75 \mathrm{ml}$ air). $\mathrm{K}_{2}=$ Konsentrasi 50\% (50 ml ekstrak bawang merah $+50 \mathrm{ml}$ air) dan $\mathrm{K}_{3}=$ Konsentrasi $75 \%$ (75 ml ekstrak bawang merah $+25 \mathrm{ml}$ air). Masing-masing perlakuan di ulang 4 kali dan setiap perlakuan dalam ulangan terdiri dari 3 unit, sehingga keseluruhan terdapat 192 bahan setek(4 x 4 × 4 × $3=192)$.

\section{Pelaksanaan Penelitian}

\section{Penyiapan Tempat}

Tempat penelitian diberikan sungkup untuk melindungi setek dari berbagai gangguan dan juga pada tempat penanaman dibuatkan rumah paranet.

\section{Penyiapan Media}

Media tanam dipersiapkan seperti tanah (top soil), pasir, sekam padi dan kompos dicampur secara merata dengan perbandingan voleme sebanyak 2:1:1:1dan dimasukan ke polybag dengan ukuran $0,5 \mathrm{~kg}$. 


\section{Pembuatan Ekstrak Bawang Merah}

Bawang merah disiapkan sebanyak $2 \mathrm{~kg}$ dengan kadar air penyimpanan kurang lebih $80 \%$, kulit terluarnya dibersihkan dan dihaluskan dengan juiser/blender kemudian disaring mengunakan kain kasa dan dijadikan larutan stok dengan konsentrasi 100\% dan dilakukan fermentasi kurang lebih selama 24 jam.

\section{Persiapan Bahan Setek}

Bahan setek kopi diupayakan seragam atas dasar jumlah 1 ruas, 1 buku, 2 daun dan bobot basah dengan penyimpangan maksimum 15\%. Jenis bahan setek yang digunakan yaitu klon kopi robusta BP308 diambil dari cabang Orthrotrop dengan panjang $7 \mathrm{~cm}$, tunas bawah dipotong miring sudut $45^{\circ}$ dan daun dipotong sesuai perlakuan.

\section{Perlakuan Perendaman}

Pengaplikasian pemberian konsen-trasi ekstrak bawang merah dilakukan dengan cara merendamkan bahan setek pada larutan sesuai perlakuan dan dosis per setek pada empat taraf konsentrasi dari masing-masing perlakuan diberikan sama, dengan perhitungan Dosis $=$ Volume $\mathrm{x}$ Konsentrasi.

\section{Penanaman Setek}

Sebelum penanaman di lakukan, media dalam polybag disiram dengan air sampai jenuh danpenanaman dilakukan langsung sesudah perlakuan perendaman dengan memasukkan seluruh batang tanaman ke media tanam dan hanya menyisakan ketiak serta seluruh bagian daun dan ujung batang diatas permukaan media tanam.

\section{Pemeliharaan}

Pemeliharaan dilakukan dengan menyiram setek setiap satu minggu sekali dengan cara mebuka sungkup dan menutup kembali sungkup dengan rapat jika sudah selesai menyiram, dan bertujuan untuk menjaga kelembaban media tetap optimum.

\section{Pengamatan}

Pengamatan dilakukan terhadap beberapa variabel meliputi waktu tumbuh tunas yang dilakukan pengamatan pada saat tuanas mulai tumbuh setinggi $5 \mathrm{~mm}$ dari pangkal tunas, sedangkan variabelpanjang tunas,diameter tunas, jumlah daun persetek, luas daun persetek, jumlah akar dan panjang akar primer dilakukan pengamatan pada umur 84 hari setelah tanam, sedangkan pada variabel berat kering oven akar, berat kering oven tunas, berat kering oven daun,koefisien partisi fotosintat dan berat kering oven total 
I GEDE BUDI YUDA KUMARA. et al. Pengaruh Pemotongan Daun dan Pemberian Konsentrasi...

setekdihitung pada umur 70 hari seteh tanam dan 84 hari setelah tanam, berat kering oven total setek merupakan penjumlah berat kering oven akar, berat kering tunas dan berat kering daun.

Pengukuran koefisien partisi fotosintat yaitu nisbah pertambahan berat kering akar, tunas dan daun dengan pertambahan total berat tanaman dilakukan dengan rumus yaitu: koefisien partisi fotosintat pada akar = $\frac{\Delta \mathrm{x} 1}{\Delta \mathrm{x} 1+\Delta \mathrm{x} 2+\Delta \mathrm{x} 3}$

koefisien partisi fotosintat pada tunas $=\frac{\Delta \times 2}{\Delta \times 1+\Delta \times 2+\Delta \times 3}$ koefisien partisi fotosintat daun = $\frac{\Delta \times 3}{\Delta \times 1+\Delta \times 2+\Delta \times 3}$

Keterangan: $\Delta=$ penambahan bobot koefisien setek kopi umur 70sampai umur 84 hari setelah tanam, $\mathrm{x} 1$ = berat kering akar, $\mathrm{x} 2=$ Berat kering tunas, $\mathrm{x} 3$ = berat kering daun.

\section{Analisis Data}

Data dianalisis dengan menggunakan analisis varian sesuai dengan rancangan yang digunakan.Apabila perlakuan berpengaruh nyata maka dilanjutkan dengan uji BNT 5\%. yang tidak nyata (Tabel 1).

\section{HASIL DAN PEMBAHASAN}

Hasil analisis statistika menunjuk-kan perlakuan pemotongan daun $(\mathrm{P})$ memberikan pengarunh sangat nyata $(\mathrm{P}>0,01)$ pada variabel panjang akar primer, berat kering oven akar, koefisien partisi fotosintat akar, koefisien partisi fotosintat daun, berat kering oven total setek. Sedangkan, untuk variabel yang lainnya menunjukkan pengaruh tidak nyata $(\mathrm{P}<0,05)$. Perlakuan konsentrasi ekstrak bawang merah $(\mathrm{K})$ menunjukkan pengaruh sangat nyata $(\mathrm{P}>0,01)$ terhadap variabel panjang akar primer, koefisien partisi fotosintat daun dan yang menunjukkan pengaruh nyata $(\mathrm{P}<0,05)$ pada variabel waktu tumbuh tunas, koefisien partisi fotosintat akar dan koefisien partisi fotosintat tunas, sedangkan untuk variabel yang lainnya menujukkan pengaruh tidak nyata $(\mathrm{P}<0,05)$. Perlakuan interaksi antara perlakuan pemotongan daun dengan konsentrasi ekstrak bawang merah ( $\mathrm{P} \quad \mathrm{X} \quad \mathrm{K})$ menunjukkan pengaruh nyata $(\mathrm{P}>0,05)$ pada variabel panjang akar primer, sedangkan untuk variabel yang lainya menunjukkan pengaruh 
Tabel 1. Signifikansi Pengaruh Pemotongan Daun (P) dan Konsentrasi Ekstrak Bawang Merah (K) Serta Interaksinya (P X K) terhadap Variabel yang Diamati

\begin{tabular}{clccc}
\hline No & \multicolumn{1}{c}{ Variabel } & $\mathrm{P}$ & $\mathrm{K}$ & $\mathrm{PXK}$ \\
\hline 1 & Waktu Tumbuh Tunas (hst) & $\mathrm{ns}$ & $*$ & $\mathrm{~ns}$ \\
2 & Panjang Tunas (cm) & $\mathrm{ns}$ & $\mathrm{ns}$ & $\mathrm{ns}$ \\
3 & Diameter Tunas (mm) & $\mathrm{ns}$ & $\mathrm{ns}$ & $\mathrm{ns}$ \\
4 & Jumlah Daun Persetek (helai) & $\mathrm{ns}$ & $\mathrm{ns}$ & $\mathrm{ns}$ \\
5 & Luas Daun Persetek $\left(\mathrm{cm}^{2}\right)$ & $\mathrm{ns}$ & $\mathrm{ns}$ & $\mathrm{ns}$ \\
6 & Jumlah Akar Primer (buah) & $\mathrm{ns}$ & $\mathrm{ns}$ & $\mathrm{ns}$ \\
7 & Panjang Akar Primer (cm) & $* *$ & $* *$ & $*$ \\
8 & Berat kering Oven Akar $(\mathrm{g})$ & $* *$ & $\mathrm{~ns}$ & $\mathrm{~ns}$ \\
9 & Berat kering Oven Tunas (g) & $\mathrm{ns}$ & $\mathrm{ns}$ & $\mathrm{ns}$ \\
10 & Berat kering Oven Daun (g) & $\mathrm{ns}$ & $\mathrm{ns}$ & $\mathrm{ns}$ \\
11 & Koefisien Partisi Fotosintat akar $(\mathrm{g})$ & $* *$ & $*$ & $\mathrm{~ns}$ \\
12 & Koefisien Partisi Fotosintat tunas $(\mathrm{g})$ & $\mathrm{ns}$ & $*$ & $\mathrm{~ns}$ \\
13 & Koefisien Partisi Fotosintat daun $(\mathrm{g})$ & $* *$ & $* *$ & $\mathrm{~ns}$ \\
14 & Berat kering Oven total Setek $(\mathrm{g})$ & $* *$ & $\mathrm{~ns}$ & $\mathrm{~ns}$ \\
\hline
\end{tabular}

\begin{tabular}{lll}
\hline Keterangan & $:$ ns & $:$ Berpengaruh tidak nyata $(\mathrm{P}<0,05)$ \\
& $*$ & $:$ Berpengaruh nyata $(\mathrm{P}>0,05)$ \\
$* *$ & $:$ Berpengaruh sangat nyata $(\mathrm{P}>0,01)$
\end{tabular}

Berat kering oven total setek kopi $25 \%, 50 \%$ dan $75 \%$ atau mengalami robusta terberat diperoleh pada pemotongan peningkatan masing-masing sebesar 48,05\%, daun $0 \%$ atau tanpa pemotongan daun $\left(\mathrm{P}_{0}\right)$ 90,00\% dan 362,16\% (Tabel 2), peningkatan yaitu 4,35 g yang menunjukkan berbeda nyata ini didukung oleh panjang akar primer ( $\mathrm{r}$ dengan pemotongan daun $25 \%, 50 \%$ dan $75 \%=0,766$ ). Dengan adanya daun pada setek atau mengalami peningkatan masing-masing dapat merangsang pertumbuhan vegetatif sebesar 20,83\%, 34,67 dan 131,38\% (Tabel lebih cepat khususnya pada akar setek kopi 2).Peningkatan berat kering oven total setek robusta, hal ini disebabkan karena hasil didukung oleh panjang akar primer $(r=$ fotositat yang terjadi di daun akan 0,766), berat kering oven akar $(r=0,940)$ merangsang pembentukan perakaran pada koefisien partisi fotosintat akar $(\mathrm{r}=0,565)$ setek. Pada jaringan daun terjadi proses dengan uji korelasi nyata positif. metabolisme yang meliputi proses

Berat kering oven akar setek kopi fotosintesis, respirasi dan transpirasi. robusta terberat diperoleh pada pemotongan daun $0 \%\left(\mathrm{P}_{0}\right)$ yaitu $3,42 \mathrm{~g}$ yang menujukkan berbeda nyata terhadap pemotongan daun 
I GEDE BUDI YUDA KUMARA. et al. Pengaruh Pemotongan Daun dan Pemberian Konsentrasi...

Tabel 2. Perlakuan Pemotongan Daun (P) dan Konsentrasi Ekstrak Bawang Merah (K) terhadap waktu tumbuh tunas (hst), Panjang akar primer $(\mathrm{cm})$, Berat kering oven akar (g) dan Berat Kering Oven Total Setek (g)

\begin{tabular}{ccccc}
\hline Perlakuan & $\begin{array}{c}\text { Waktu } \\
\text { Tumbuh } \\
\text { Tunas (hst) }\end{array}$ & $\begin{array}{c}\text { Panjang } \\
\text { Akar Primer } \\
(\mathrm{cm})\end{array}$ & $\begin{array}{c}\text { Berat } \\
\text { Kering } \\
\text { Oven Akar } \\
(\mathrm{g})\end{array}$ & $\begin{array}{c}\text { Berat } \\
\text { Kering } \\
\text { Oven Total } \\
\text { Setek }(\mathrm{g})\end{array}$ \\
\hline $\begin{array}{c}\text { Pemotongan daun } \\
(\mathrm{P})\end{array}$ & & & \\
$\mathrm{P}_{0}$ & $185.88 \mathrm{a}$ & $38.80 \mathrm{a}$ & $3.42 \mathrm{a}$ & $4.35 \mathrm{a}$ \\
$\mathrm{P}_{1}$ & $172.88 \mathrm{a}$ & $28.68 \mathrm{~b}$ & $2.31 \mathrm{~b}$ & $3.60 \mathrm{~b}$ \\
$\mathrm{P}_{2}$ & $184.00 \mathrm{a}$ & $16.80 \mathrm{c}$ & $1.80 \mathrm{c}$ & $3.23 \mathrm{c}$ \\
$\mathrm{P}_{3}$ & $178.63 \mathrm{a}$ & $16.60 \mathrm{c}$ & $0.74 \mathrm{~d}$ & $1.88 \mathrm{~d}$ \\
\hline BNT 5\% & & 1.54 & 0.27 & 0.37 \\
\hline Konsentrasi ekstrak & & & & \\
bawang merah (K) & $186.25 \mathrm{a}$ & $23.68 \mathrm{~b}$ & $2.18 \mathrm{a}$ & $3.38 \mathrm{a}$ \\
$\mathrm{K}_{0}$ & $172.88 \mathrm{c}$ & $29.85 \mathrm{a}$ & $2.30 \mathrm{a}$ & $3.84 \mathrm{a}$ \\
$\mathrm{K}_{1}$ & $179.38 \mathrm{~b}$ & $28.53 \mathrm{a}$ & $1.98 \mathrm{a}$ & $3.14 \mathrm{a}$ \\
$\mathrm{K}_{2}$ & $185.50 \mathrm{a}$ & $18.83 \mathrm{c}$ & $1.81 \mathrm{a}$ & $2.71 \mathrm{a}$ \\
$\mathrm{K}_{3}$ & 3.53 & 1.54 & & \\
\hline BNT 5\% & & &
\end{tabular}

Keterangan : Angka-angka yang diikuti huruf sama pada kolom yang sama menunjukkan berbeda tidak nyata berdasarkan uji BNT 5\%

Luas daun pada setek dapat selama ada penguapan. Pergerakan ini terjadi mempengaruhi besar kecilnya transpirasi karena tidak membutuhkan energi, maka yang terjadi pada setek, tetapi dengan peristiwa ini disebut transpirasi pasif.Menurut memperhatikan penyiraman yang dilakukan Irwanto (2003dalamEnindhita 2011), satu minggu sekali akan mampu menjaga kelembaban di dalam media setek harus ketersedian air di tanah dengan jumlah yang tinggi dan dipertahankan mendekati 90\%, optimal sehingga terjadi transpirasi yang agar tidak terjadi transpirasi yang besar pada optimum. Hara bergerak karena ada gradien setek.

potensial air. Aliran massa terjadi akibat Interaksi pemotongan daun dengan adanya gaya tarik menarik antara molekul- pemberian konsentrasi ekstrak bawang merah molekul air yang digerakkan oleh lepasnya ( $\mathrm{P}$ X K) variabel panjang akar primer yang molekul air melalui penguapan atau terpanjang didapat pada interaksi pemotongan transpirasi. Demikian tarik-menarik ini terjadi daun $0 \%$ dengan pemberian konsentrasi 
ekstrak bawang merah $25 \%\left(\mathrm{P}_{0} \mathrm{~K}_{1}\right)$ yaitu pengatur tumbuh yang mengandung hormon dengan rata-rata panjang akar primer $51,9 \mathrm{~cm}$ auksin mampu memberikan pertumbuhan dan menga-lami peningkatan $226.42 \%$ jumlah dan panjang akar yang lebih tinggi dibandingkan panjang akar primer terpendek dibandingkan dengan setek yang tidak yaitu $15,9 \mathrm{~cm}$ pada interaksi perlakuan $\left(\mathrm{P}_{3} \mathrm{~K}_{1}\right)$ diberikan perlakuan zat pengatur tumbuh. pemotongan daun $75 \%$ dengan pemberian Sedangkan menurut Mangoendijodjojo konsentrasi ekstrak bawang merah 25\%. (2003) keberadaan daun pada bahan setek (Tabel 3). Pada pemotongan daun $0 \%$ atau merupakan pendorong pembentukan akar, tanpa pemotongan daun memiliki panjang tetapi apabila terlalu banyak jumlahnya dapat akar primer yang terbaik pada tiap level meningkatkan intensitas penguapan sehingga konsentrasi ekstrak bawang merah (K) pembentu-kan akar terhambat.

dibandingkan perlakuan yang lainnya.

Menurut Nurlaeni (2015), pemberian zat

Tabel 3. Interaksi Pemotongan Daun dengan Konsentrasi Ekstrak Bawang Merah terhadap Panjang Akar Primer $(\mathrm{cm})$

\begin{tabular}{ccccc}
\hline Pemotongan daun & \multicolumn{4}{c}{ Konsentrasi ekstrak bawang merah (K) } \\
\cline { 2 - 5 }$(\mathrm{P})$ & $\mathrm{K}_{0}$ & \multicolumn{1}{c}{$\mathrm{K}_{1}$} & $\mathrm{~K}_{2}$ & $\mathrm{~K}_{3}$ \\
\hline $\mathrm{P}_{0}$ & $36.7 \mathrm{~b}$ & $51.9 \mathrm{a}$ & $42.0 \mathrm{ab}$ & $24.6 \mathrm{c}$ \\
$\mathrm{P}_{1}$ & $24.2 \mathrm{c}$ & $31.6 \mathrm{bc}$ & $39.2 \mathrm{~b}$ & $19.7 \mathrm{~cd}$ \\
$\mathrm{P}_{2}$ & $18.0 \mathrm{~cd}$ & $20.0 \mathrm{~cd}$ & $13.3 \mathrm{~d}$ & $15.9 \mathrm{~cd}$ \\
$\mathrm{P}_{3}$ & $15.8 \mathrm{~cd}$ & $15.9 \mathrm{~cd}$ & $19.6 \mathrm{~cd}$ & $15.1 \mathrm{~cd}$ \\
\hline
\end{tabular}

Keterangan :Angka-angka yang diikuti huruf sama pada menunjukkan perbedaan yang tidak nyata berdasarkan uji Jarak Berganda Duncan taraf 5\%

Pertumbuhan perakaran yang baik akan menyatakan akar merupakan organ vegetatif mempengaruhi keadaan organ lainya. yang menyerap air, mineral dan bahan-bahan Pertambahan jumlah dan panjang akar akan yang penting untuk pertumbuhan dan meningkatkan daya serapan air maupun hara perkembangan tanaman. Cepat lambatnya oleh tanaman, sehingga aktivitas fotosintesis saat muncul tunasakan mempengaruhi tanaman berjalan dengan baik dan membatu panjang tunas,sehingga tunas yang tumbuh pertumbuhan organ vegetatif lainnya seperti lebih cepatakan menghasilkan tunas yang tunas. Hasil fotosintesis yang lebihpanjang. Hal ini ditunjukkan dengan ditranslokasikan ke akar digunakan sebagai kolerasi antara jumlah daun dengan diameter keperluan pertumbuhan akar, sedangkan yang tunas $\left(\mathrm{r}=0,575^{*}\right)$ dan panjang tunas $(\mathrm{r}=$ ke tajuk untuk pertumbuhan tajuk $0,763 *)$. Selanjutnya, tunas yang tumbuhlebih terutamanya pada tunas. Pearce et al. (1991) panjang akan memiliki tempattumbuh daun 
I GEDE BUDI YUDA KUMARA. et al. Pengaruh Pemotongan Daun dan Pemberian Konsentrasi...

yang lebih banyakdibandingkan dengan tunas yang pendek. Auksin secara tidak langsung berperandalam mening-katkan jumlah daun melalui pembentukan ruasbaru pada setek kopi robusta. Karnedi (1998 dalam Fanesa, 2011) jumlah daun erat hubungannya dengan panjang tunas. Jumlah daun akan bertambah seiring dengan panjang tunas, tanaman yang memiliki tunas lebih panjang akan menyebabkan bertambahnya jumlah ruas tempat tumbuhnya daun.

Tabel 4. Perlakuan Pemotongan Daun (P) dan Konsentrasi Ekstrak Bawang Merah (K) terhadap Koefisien Partisi Fotosintat

\begin{tabular}{cccc}
\hline \multirow{2}{*}{ Perlakuan } & \multicolumn{3}{c}{ Koefisien partisi fotosintat $(\mathrm{g})$} \\
\cline { 2 - 4 } & Akar & Tunas & Daun \\
\hline Pemotongan daun (P) & & & \\
$\mathrm{P}_{0}$ & $2.41 \mathrm{a}$ & $0.33 \mathrm{a}$ & $0.24 \mathrm{~d}$ \\
$\mathrm{P}_{1}$ & $1.73 \mathrm{~b}$ & $0.57 \mathrm{a}$ & $0.63 \mathrm{c}$ \\
$\mathrm{P}_{2}$ & $1.48 \mathrm{c}$ & $0.54 \mathrm{a}$ & $1.02 \mathrm{~b}$ \\
$\mathrm{P}_{3}$ & $1.07 \mathrm{~d}$ & $0.53 \mathrm{a}$ & $1.46 \mathrm{a}$ \\
\hline BNT 5\% & 0.14 & & 0.1 \\
\hline Konsentrasi ekstrak & & & \\
bawang merah (K) & & & $0.82 \mathrm{~b}$ \\
$\mathrm{~K}_{0}$ & $1.71 \mathrm{~b}$ & $0.46 \mathrm{~b}$ & $1.14 \mathrm{a}$ \\
$\mathrm{K}_{1}$ & $1.25 \mathrm{c}$ & $0.68 \mathrm{a}$ & $0.90 \mathrm{~b}$ \\
$\mathrm{~K}_{2}$ & $1.75 \mathrm{~b}$ & $0.39 \mathrm{c}$ & $0.49 \mathrm{c}$ \\
$\mathrm{K}_{3}$ & $1.98 \mathrm{a}$ & $0.43 \mathrm{bc}$ & 0.1 \\
\hline BNT 5\% & 0.14 & 0.06 & $\mathrm{yana}$
\end{tabular}

Keterangan: Angka-angka yang diikuti huruf sama pada kolom yang sama menunjukkan berbeda tidak nyata berdasarkan uji BNT 5\%

Data analisis statistik pada variabel yang berpengaruh nyata selain koefisien koefisien partisi fotosintat (Tabel 4), partisi fotosintat tunas yang menujukkan perlakuan pemberian konsentrasi ekstrak berpengaruh tidak nyata. Koefisien partisi bawang merah $(\mathrm{K})$ berbeda nyata pada fotosintat menggambarkan banyak sedikitnya variabel koefisien partisi fotosintat akar, tunas fotosintat yang dialirkan ke bagian tanaman dan daun. Sedangkan, pemotongan daun (P) pada fase pertumbuhan vegetatif yaitu akar, berbeda nyata pada variabel koefisien partisi tunas dan daun. Pada fase vegetatif tanaman fotosintat akar dan daun. Akan tetapi pada aktif membentuk bagian vegetatif seperti koefisien partisi fotosintat tunas menujukkan akar, tuans dan daun sehingga fotosintat reaksi tidak berbeda nyata. Hal ini ditranslokasikan kebagian tersebut, oleh mengindikasikan bahwa pertumbuhan setek sebab itu kompetisi akan terjadi di antara kopi robusta dengan perlakuan yang berbeda bagian tersebut untuk memperebutkan menghasil-kan koefisien partisi fotosintat fotosintat, hal ini berbading lurus dengan 
kenyataan yang dimana pemotongan daun dapat memberi-kan hasil yang berpengaruh nyata terhadap koefisien partisi fotosintat akar dan daun.

\section{SIMPULAN}

Terjadi interaksi yang nyata anatara pemotongan daun $0 \%$ dengan pemberian konsentrasi ekstrak bawang merah 25\% terhadap panjang akar primer. Perlakuan pemotongan daun $0 \%$ atau tanpa pemotongan daun membuat pertumbuhan setek terbaik, terlihat dari berat kering oven total setek yang tertinggi, yaitu 4,35g atau meningkat secara nyata masing-masing sebesar 20,83\%, $34,68 \%$ dan $131,38 \%$ dibanding dengan pemotongan daun $25 \%, 50 \%$ dan $75 \%$. Pemberian konsentrasi ekstrak bawang merah $25 \%$ memberikan pertumbuhan setek kopi robusta yang terbaik yaitu pada waktu tumbuh tunas, panjang akar primer, koefisien partisi fotosintat tunas dan koefisien partisi fotosintat daun serta berbeda nyata dibanding dengan pemberian perlakuan konsentrasi yang lainnya. Pemberian konsentrasi ekstrak bawang merah $75 \%$ memberikan pertumbuhan setek kopi robusta yang terbaik yaitu pada koefisien partisi fotosintat akar serta berbeda nyata dibanding dengan pemberian perlakuan konsentrasi yang lainnya.

\section{DAFTAR PUSTAKA}

Direktorat Jenderal Perkebunan. 2016. Statistik Perkebunan Kopi di Indonesia Tahun 2015-2017

Direktorat Jenderal Perkebunan. 2017. Statistik Perkebunan Kopi di Indonesia Tahun 2015-2017.

Enindhita, K. 2011.Pengaruh Pemberian ZPT (rootone-f) terhadap Pertumbuhan Setek
Duabanga noluccana, Blume.Skripsi Fakultas Kehutanan Institut Pertanian Bogor.

Hafizah, N. 2014.Pertumbuhan Setek Mawar (Rosa damascena Mill.) pada Waktu Perendaman dalam Larutan Urine Sapi. Ziraa'ah 39(3): 129 - 135.

Fanesa. A. 2011. Pengaruh Pemberian Beberapa Zat Pengatur Tumbuh Terhadap Pertumbuhan Setek Pucuk Jeruk Kacang (Citrus nobilis L.). Jurnal Pertanian. Fakultas Pertanian Unand.

Mangoendidjojo. 2003. Dasar-dasar PemuliaanTanaman. Kanisius: Yokyakarta.

Marfirani, M., S. R. Yuni, dan Evie, R. 2014. Pengaruh Berbagai Konsentrasi Filtrat Umbi Bawang Merah dan Rootone F terhadap Pertumbuhan Stek Melati

Nurlaeni, Y. dan M.I. Surya. 2015. Respon Setek Pucuk Camelia japonica terhadap Pemberian Zat Pengatur Tumbuh Organik. Pros Sem Nas Masy Biodiv Indon 1: 1211-1215.

Pearce R. B., F. P Gardner, dan R. L. Mitchell. 1991. Physiology of Crop Plants (Edisi Terjemahan). UI Press. Jakarta. 428 hlm.

Siregar, A., P. E. Zuhry, dan Sampoerno. 2015. Pertumbuhaan Bibit Gaharu (Aquilaria malaccencis) dengan pemberian zat pengatur tumbuh asal bawang merah. J. Jom Faperta 2(1):1-2.

Utami, Hermansyah dan Handajaningsih, M. 2015. Respon Pertumbuhan Setek Anggur (Vitis vinifera L.) terhadap Pemberian Beberapa Konsentrasi Ekstrak Bawang Merah (Allium ascalonicum L.). Fakultas Pertanian Universitas Bengkulu. Bengkulu.

Wulandari, F., M. Astiningrum dan Tujiyanta. 2017. Pengaruh Jumlah Daun dan Macam Media Tanam pada Setek Jeruk Nipis.Fakultas Pertanian Universitas Tibar.Magelang. 